\title{
The Role of Web Design, E-WOM and City Branding on Re-Visit Behaviour
}

\author{
Ariani Kusumo Wardhani \\ Universitas Mercu Buana \\ Tan Tse Guan \\ Universiti Malaysia Kelantan
}

\begin{abstract}
The increasing number of Internet users, especially in Indonesia, the parties who make strategic decisions in the domain of Tourism should focus their attention toward the testimony and the information that have been circulating around the social media, especially with regards to the domain of Tourism. By paying attention to the above factors, through the conduct of the study the researcher would like to focus on the influence of Web Design, E-WOM and City Branding on the Re-Visit Behaviour to a tourism destination. In conducting the study, the researcher adopted the TPB (Theory of Planned Behaviour) that serves as the basis in identifying the factors that influence the tourist to visit a tourism destination. In the same time, the researcher will also adopt the TRA (Theory of Reaction Action), which later associated to the underlying theory in confirming the factors that influence the tourist's decision to visit a tourism destination. Moreover, in analysing the respondents' characteristics within the study, the researcher had run by the SPSS software. This research used SEM PLS in analyzing the data. The research distributed questionnaires to the tourists who used to visit a tourism destination located in the Regency of Pandeglang, Indonesia. Finally, his research found that web design, e- wom and city branding have positive and significant impact on visit decision
\end{abstract}

Keywords: Web Design, E-WOM, City Branding, Visit Decision, Theory of Planned Behaviour, Theory of Reaction Action

DOI: $10.7176 /$ RHSS/10-6-03

Publication date:March $31^{\text {st }} 2020$

\section{Introduction}

The areas in Banten that has been well-known as a tourism destination is the Regency of Pandeglang. The Regency of Pandeglang has been very famous as a tourism object. The Regency has numerous tropical tourism area such as Anyer Beach, Carita Beach, Lesung Cape, Umang Island, Oar Island, Peucang Island and Ujung Kulon National Park. Specific to Ujung Kulon National Partk, in this National Park tourists might view the one-horned rhinoceros and these rhinoceros only live in Ujung Kulon National Park. The competitive edge of a region nowadays has been the attention of the experts especially in relation to marketing and branding activities. One of the best ways to forge the inter-region competitive edge is creating a strong brand by reflecting the regional identity in order to draw the potential customers, tourists, investors and even residents. In other words, brand might be considered as a differentiator that clearly becomes the ultimate weapon for the competitive edge of a city. Then, the objective of branding itself is to improve the business investment relationship, to improve the competitive position in the tourism market, to promote the social and economic development in general and also to encourage the community to identify their residence.

Cities need identity that will differentiate them from one to another. The needs toward a identify might be fulfilled by a brand in the form of name, logo, sign, design and the combination of all of these aspects. Cavia Fernandez et al. (2013) explains that branding is not viewed as the way to manage a city but branding is viewed as the medium for delivering positive impression which aims to improve the perception that numerous stakeholders have in their mind. Therefore, branding will not change a city but branding will help improving the overall competitive edge. Specific to the context of the study, if city branding is able to create positive impression in the tourists' mind then tourists' behaviours before and after visiting a tourism destination will change. According to Aaker (2012), a strong brand might create an impression. This statement is supported by the argument from Kavaratzis \& Ashworth (2005), which state that creating city branding might influence the mental map or, in other words, creating city branding might influence how the tourists perceive a city in their mind.

The phenomenon of city competition through marketing techniques known as city branding refers to the identification toward a set of brand attributes that have been possessed by a city in accordance to the given order to in order to provide the foundation that will serve to generate the positive perception from a number of audiences. In Indonesia, there have been several big cities that implementing the city branding program well. For example, the City of Yogyakarta used to implement the brand "Jogja Never Ending Asia" and in 2015 the brand was replaced by the new one namely "Jogja Istimewa." Then, the Province of Bali has implemented the brand "Santhi Santhi Santhi." Furthermore, the City of Solo has made use of six slogans and one of these slogans is "The Spirit of Java." 
On the other hand, the City of Surabaya has implemented the slogan "Sparkling Surabaya." Last but not the least, the Regency of Pandeglang has made use of the brand "Sunset of Java." This branding focuses on increasing the visit interest of both the domestic and the foreign tourists. The Regency of Pandeglang has famous and beautiful tourism destinations with all the mountains and the coastlines. The data on the number of both the domestic and the foreign tourists within the last three years, namely from $2015-2017$, might be consulted in Table 1 below.

Table 1.1 Development on the Number of Visits by the Domestic and the Foreign Tourists in the Regency of Pandeglang from 2015 until 2017

\begin{tabular}{lrrr}
\hline \multicolumn{1}{c}{ REGENCY/CITY OF PANDEGLANG } & \multicolumn{3}{c}{ Year } \\
\\
\hline Domestic Tourists & 2015 & \multicolumn{1}{c}{2016} & \multicolumn{1}{c}{2017} \\
Foreign Tourists & $3,357,779$ & $3,591,587$ & $3,831,072$ \\
\hline
\end{tabular}

Source : Province of Banten Office of Tourism

From the data in Table 1.1 above, it might be concluded that within the last three years the number of visit by the domestic tourists has been increasing. The situation is different on the number of visit by the foreign tourists. The number of visit by the foreign tourists has been decreasing from one year to another.

Tourists will look for information about the tourism package within a tourism destination from a number of angles and the demanded information. Thus, the low management on the tourism product within a destination will be heavily influential for the tourists with regards to their visit. The examples on the case of low management are the poor management of tourism attraction within a destination, the low service that has been delivered to the tourists or the less responsive manager in following up the complaints from the visitors, the expensive price of the tickets, the lack of supporting facilities and cleanliness in the tourism destinatio, the absence of map or information in the tourism area (leading to the confusion among the tourists) and the lack of signs toward the tourism destination. All of these examples might be the point of consideration for the tourists prior to their decision-making activities with regards to a destination (Ardiayanto, 2017).

Most of the potential visitors will look for any information first prior to visit the tourism destination. This information might be available in the social media such as Instagram, Facebook and Twitter or from the other visitors who have been to the desired tourism destinations. As having been proposed by Bataineh (2015) in his study, the potential visitors who act as the information retriever will easily trust the highly credible and wellqualified information with accurate quantity in accordance to the facts in the field. Therefore, a web design that is able to provide good information will be one of the factors that the potential visitors consider prior to their decision in visiting certain tourism destinations.

It is in such situation that E-WOM exerts its power as the greatest attraction of a tourism destination. Heaningthurau (2004) states that E-WOM is a form of marketing communication that contains positive and negative statements proposed by the potential customers through Internet. This definition is in line with the definition proposed by Eaton (2006), which states that E-WOM refers to the immediate act of disseminating information or of performing promotional activities in the domain of Internet. With regards to the two definitions, the social media that have been frequently visited by the potential customers are Facebook, Instagram and Twitter. Finally, this study examines the impact of web design, e-wom and city branding on re-visit intention.

\section{Literature Review and Hypothesis Development}

In this chapter, the researcher would like to review the underlying theories for the conduct of the study and also to develop the hypotheses and the framework for the conduct of the study. The theories that will be reviewed within the conduct of the study are related to theory of Tourism Marketing. The theory, the hypotheses and the research framework might be consulted in the following sections.

\subsection{Toursim Marketing}

Tourism marketing might be considered as the aspects that a marketer performs in pursuing the marketing business such as promotion, market segment identification, positioning and alike in relation to the tourism products such as tourism objects tourism facilities, and even tourism services. Not to mention, the tourism product itself is a product of service business. Then, in marketing tourism there should be an in-depth understanding toward the product that has been under possession and on sale. Similar principle also applies to the perceptions and the preferences of the tourists, which will trigger the behaviours that encourage the purchase process. The above explanation is in line with the definition of tourism marketing by Wahab, Crampon \& Rothfield (1976). In their opinion, tourism marketing is a managerial process that has been conducted by the national tourism organizations or companies, including the tourism industry groups, in order to identify the tourists who have already had desires to take tourism journey by: establishing communication with these tourism organizations or companies; influencing the needs and the desires of the potential tourists; motivating the potential tourists to visit certain tourism destinations; and identifying the likes and the dislikes of the potential tourists in local, regional, national and even international level 
through the provision of tourism object and attraction so that the potential tourists will gain their satisfaction.

The results of several studies that have been conducted previously identify several factors that become the matter of consideration among the tourists prior to take any visit decision. Among these factors, there are namely Web Design, E-WOM and City Branding (Mohsen, Jayashree, Razel \& Kazim, 2018; Ashwort, 2005; Eaton, 2006).

\subsection{Hypothesis Development}

After gathering the theories that might support the conduct of the study, the researcher would like to define the hypotheses that will be further investigated within the study. These hypotheses are proposed in relation to the topic of the study and also the theories that have been reviewed within the study. Thus, the hypotheses might be consulted in the following section.

The Influence of Web Design on Revisit Behaviour

In relation to the conduct of the study, web design refers to the theory of brand impression. According to the theory of brand impression, a brand might provide an inseparable description of a product. Specifically, in the study the product that will be investigated is the tourism product. Therefore, web design might be defined as the public perception toward the identify of a company or an association (Arafat, 2006 in Suawduki, Yuoianto \& Mawardi, 2016). Furthermore, user-friendly web design will be one of the consideration factors for the tourists to make their decision on visiting a destination (Baitaneh, 2015). Departing from this elaboration, the researcher would like to propose the first hypothesis as follows:

$H_{1}$ : Web Design has positive and significant influence on Re-Visit Behaviour

The Influence of City Branding on Re-Visit Behaviour

City branding is a process or an effort of creating brand from a city in order to ease the stakeholders of the given city to introduce their city to the targeted market (investors, tourists, talents and events) by means of positioning, slogan, icon, exhibition and other media (Prasetyo, 2012). According to Cardwell \& Freire (2004, in Knape \& Lundell, 2011), the term brand has main relevance as a strategic marketing tool and the sample principle applies for both the product brand and the service brand. Based on the results of a study by Amellia, Achmad \& Ari (2018), it is found that City Branding has significant influence on Visit Decision. Departing from this elaboration, the researcher would like to propose the second hypothesis as follows:

\section{$\mathrm{H}_{2}$ : City Branding has positive and significant influence on Re-Visit Behaviour}

The Influence of E-WOM on Re-Visit Behaviour

According to Swasta \& Handoko (2012), visit decision that has been made by the customers are based on a number of decisions. The results of a study by Fungkiya Sari et al. (2018), state that customers or visitors make their decisions by viewing several decision items such as popularity, peculiar facility and supporting reviews. In relation to the previous statements, E-WOM refers to the marketing communication that has been performed online through social media (Schiffman \& Kanuk in Haekal, 2016). Departing from this elaboration, the researcher would like to propose the third hypothesis as follows:

$H_{3}:$ E-WOM has positive and significant influence on Re-Visit Behaviour.

\subsection{Research Framework}

Based on the theories that have been reviewed and also the hypotheses that have been proposed, the researcher framework for the conduct of the study might be defined as follows:

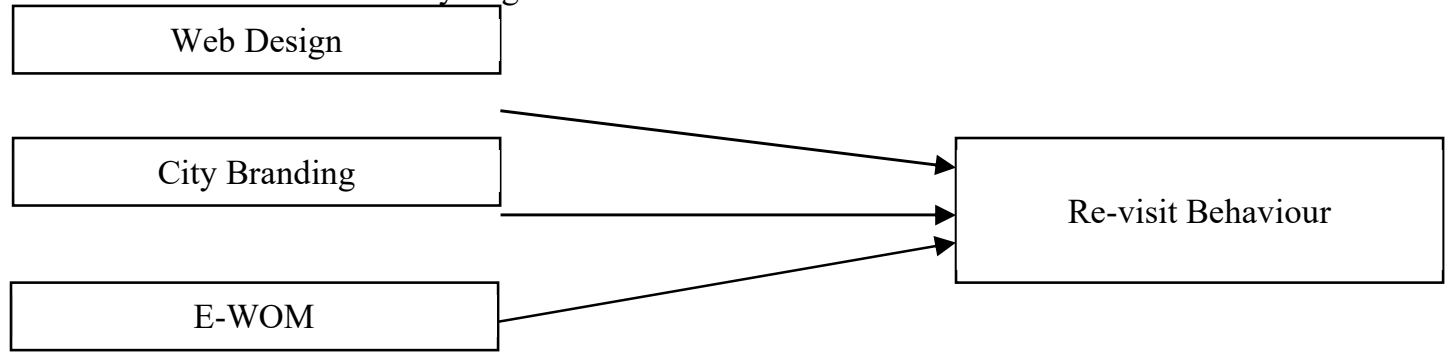

Figure 2.1 Research Framework

\subsection{Research Methodology}

The Component/Variance-Based Structural Equation Modelling is an alternative of the Covariance-Based Structural Equation Modelling. This Component/Variance-Based Structural Equation Modelling is also known as Partial Least Square (PLS). This method is intended to perform the causal-predictive analysis within the situations of high complexity and low theoretical support. In line with the intention, the aim of PLS is to find the predictive linear variable among the variables (the component-based predictive model) (Ghozali, 2014). The procedures that should be proposed for meeting the assumptions of the variance-based SEM become the guidelines for the variance-based SEM modelling both within the data gathering process and within the data processing by means of 


\section{Smart PLS 3.}

\subsection{Analysis}

The Component/Variance-Based Structural Equation Modelling is an alternative of the Covariance-Based Structural Equation Modelling. This Component/Variance-Based Structural Equation Modelling is also known as Partial Least Square (PLS). This method is intended to perform the causal-predictive analysis within the situations of high complexity and low theoretical support. In line with the intention, the aim of PLS is to find the predictive linear variable among the variables (the component-based predictive model) (Ghozali, 2014). The procedures that should be proposed for meeting the assumptions of the variance-based SEM become the guidelines for the variance-based SEM modelling both within the data gathering process and within the data processing by means of Smart PLS 3.

\section{Measurement Model}

Convergent Validity

The convergent validity test of the measurement model with the reflexive indicators is assessed based on the correlation between the item score/component score and the construct score that has been calculated by using the PLS. The individual indicators will be considered valid if the correlation value is higher than 0.70 .

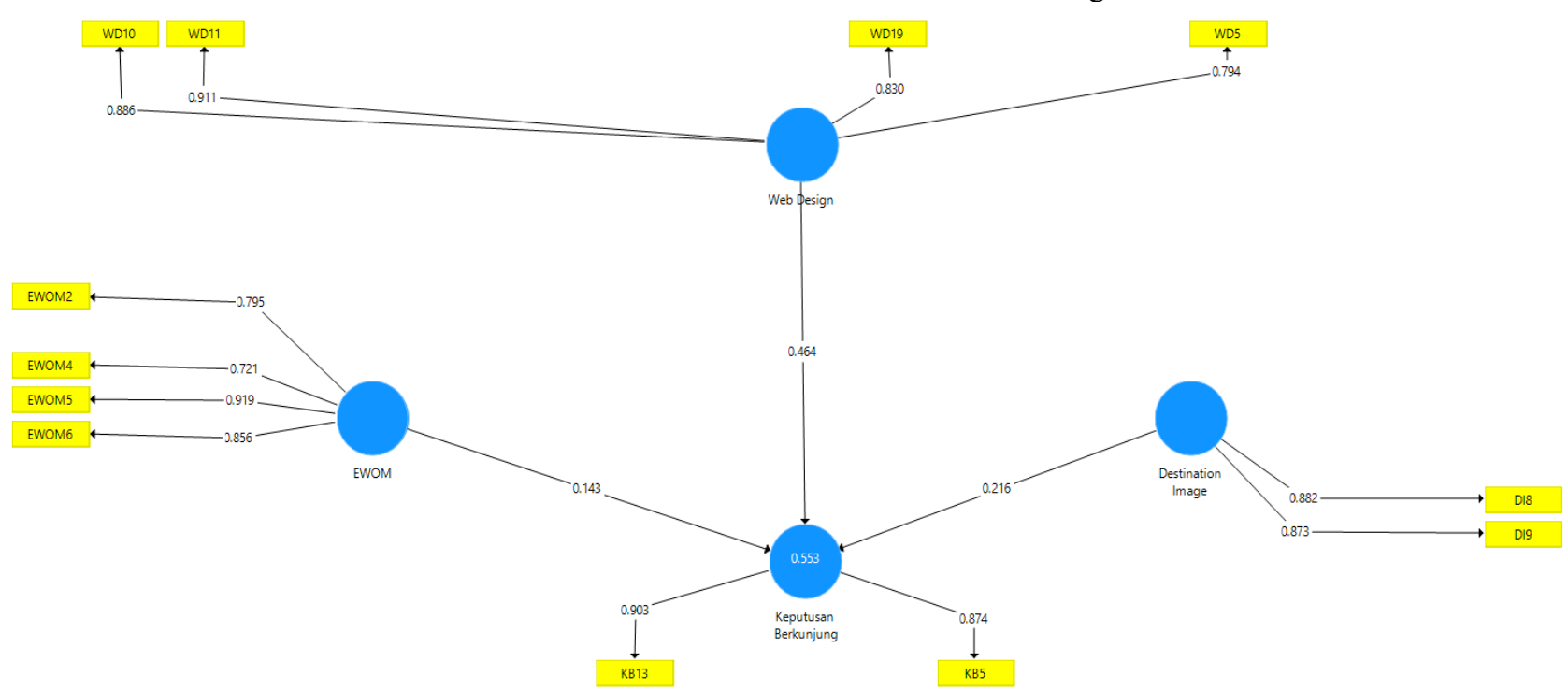

Figur3.1. Results of PLS Algorithm

Discriminant Validity

For the conduct of the discriminant validity test, the reflexive indicators might be consulted on the cross-loading value between the indicators and the constructs. An indicator is considered valid if the value of the loading factor is the highest relative to the targeted construct in comparison to the loading factor value of the other construct. Thereby, the latent constructs are able to predict the indicators in their own block better than the indicators in the other block.

Table 3.1. Result of AVE

\begin{tabular}{lc}
\hline & AVE \\
\hline City Branding & 0.770 \\
EWOM & 0.683 \\
Re-Visit Behaviour & 0.789 \\
Web Design & 0.734 \\
\hline
\end{tabular}


Table 3.2. Results of Discriminant Validity Test (Fornell Lacker Criterum)

\begin{tabular}{lrrrr}
\hline & City Branding & E-WOM & Re-Visit Behaviour & Web Design \\
\hline City Branding & 0.877 & & & \\
EWOM & 0.575 & 0.826 & & \\
Re-Visit Behaviour & 0.619 & 0.605 & 0.888 & \\
Web Design & 0.691 & 0.727 & 0.717 & 0.857 \\
\hline
\end{tabular}

From the results in Table 3.1 and 3.2 above, it might be concluded that the square root of the Average Variance Extracted (AVE) for each construct has been higher than the correlation value between one construct and another within the model. From the AVE Value, it might be concluded that the construct within the model that has been estimated already meets the discriminant validity criteria.

Composite Reliability

The composite reliability test aim at testing the reliability of the instrument within a research model or at measuring the internal consistency. The value of the composite reliability and Cronbach's alpha test should be higher than 0.60. If all of the latent variables have the both the composite reliability test score and the Cronbach's alpha test score that has been equal to or higher than $0.70(\geq 0.70)$ then the indication will be that the constructs have good reliability or the questionnaire that has been implemented as the data gathering tool in the study has been reliable or consistent.

Table 3.3. Results of Composite Reliability

\begin{tabular}{lr}
\hline & Composite Reliability \\
\hline City Branding & 0.870 \\
EWOM & 0.895 \\
Re-Visit Behaviour & 0.882 \\
Web Design & 0.917 \\
\hline
\end{tabular}

Based on the results in Table 3.3 above, it is apparent that the composite reliability test has shown satisfying results since the composite reliability value of all latent variables have been equal to or higher than $0.70(\geq 0.70)$.

\section{Structural Model}

The inner model measurement or the inner model test refers to the development of the concept and theory-based model in order to analyse the relationship between the exogenous variable and the endogenous variable that has been elaborated in the conceptual framework. The stage in the inner model test, or also known as the structural model test, consists of the procedures that will be elaborated below.

R-Square.

Table 3.4 $\mathrm{R}^{2}$ Value of the Endogenous Variable

\begin{tabular}{ll}
\hline \multicolumn{3}{c}{ R Square } \\
\hline Purchase Decision & 0.553
\end{tabular}

The structural model indicates that the model in the Re-Visit Behaviour might be considered moderate because the R-Square value ranges between 0.33 and 0.67 . Then, the model of the latent independent variable (namely Web Design, E-WOM and City Branding) influence on Re-Visit Behaviour shows that the R-Square value has been 0.553 . In other words, it might be interpreted that the variability of the constructs in Web Design, EWOM and City Branding has been $55.30 \%$ while the remaining $44.70 \%$ variability might be explained by the constructs of the other variables that have not been included into the study

Goodness of Fit Model

The Goodness of Structural Model test in the Inner Model Measurement makes use of the Predictive-Relevance $\left(\mathrm{Q}^{2}\right)$ value. The Q-Square Value that has been higher than 0 (zero) shows that the model has the predictiverelevance value. The R-Square Value of each endogenous variable in the study might be viewed in the following calculation:

$Q^{2}=\sqrt{R^{2} \times A V E}$

$Q^{2}=\sqrt{0.553 \times 0.744}$

$Q^{2}=\sqrt{0.411432}$

$Q^{2}=0.641$

The result of the above calculation shows that the Predictive-Relevance Value has been $0.641(>0.000)$. The implication of the value is that $64.10 \%$ variance on the variable Re-Visit Behaviour might be explained by the variables that had been used. Thereby, the model has been considered fit for attaining the relevant predictive value. 
Hypothesis Test (Path Coefficient)

The estimates value for the path relationship in the structural model should be significant. The significant value might be attained by using the bootstrapping procedures. The significance value in the hypothesis might be viewed by looking at the parameter coefficient value and the T-statistics significance value in the algorithm bootstrapping report. In order to identify whether the estimates value is significant or insignificant, the T-table at alpha $0.05(5 \%)$ $=1.96$ might be used. Then, the T-table value should be compared to the T-count value (T-statistics). The figure below shows that the result of structural model .

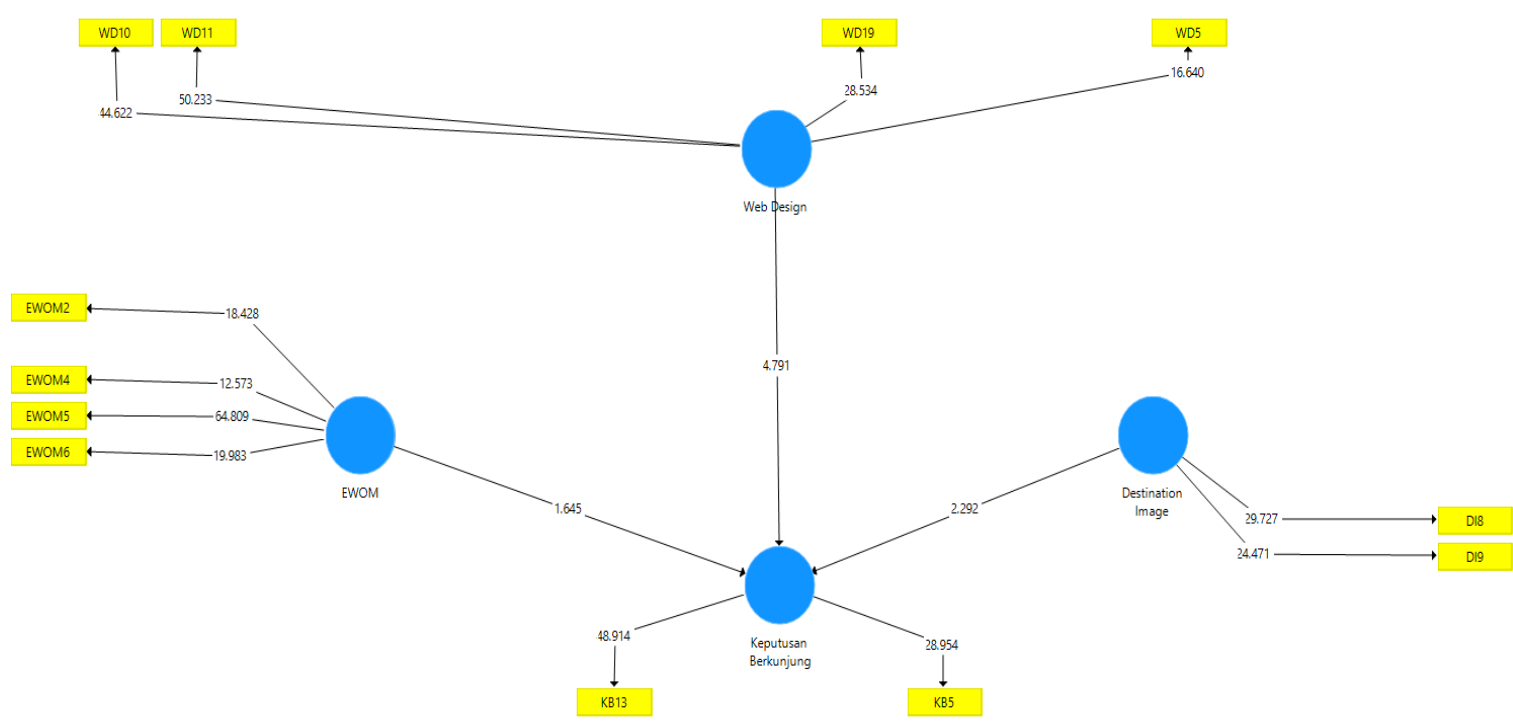

Figure 3.2. Structural Model

According to figure 2, all the predictor variable have positive and significant impact on purchasing decision. The conclusion of the result of hypothesis testing explains on the table 3.5 below:

Table 3.5. Results of Hypothesis

\begin{tabular}{|c|c|c|c|c|}
\hline & $\begin{array}{c}\text { Original Sample } \\
\text { (O) }\end{array}$ & $\begin{array}{l}\text { Standard } \\
\text { Deviation } \\
\text { (STDEV) }\end{array}$ & T-Statistics & Status \\
\hline $\mathbf{C B} \rightarrow \mathbf{R B}$ & 0.216 & 0.094 & 2.292 & Positive $\rightarrow$ Significant \\
\hline E-WOM $\rightarrow$ RB & 0.143 & 0.087 & 1.645 & Positive $\rightarrow$ Insignificant \\
\hline $\mathbf{W D} \rightarrow \mathbf{R B}$ & 0.464 & 0.097 & 4.791 & Positive $\rightarrow$ Significant \\
\hline
\end{tabular}

Based on the hypothesis test in this study the results of the T-statistic value of web design were 2.292 and the original sample value was 0.216 . The T-statistic value is more than the T-table value of 1.96 and the original sample value shows a positive value, this result shows that web design has a positive and significant effect on revisit behaviour. In other hand, e-wom has positive and not significant impact on re-visit behaviour, it was reflected by the value of T statistic 1.645 (lower than 1.96). Furthermore, city branding has positive and significant impact on purchasing decision that proved by the value of T statistic 4.791 (greater than 1.96).

\section{Discussion}

The first hypothesis (H1) states that Web Design has positive and significant influence on Re-Visit Behaviour. The T-statistics value for the first hypothesis is $4.791(>1.96)$. The positive path coefficient value indicates the linear relationship and thus it confirms that the respondents decide to visit Pandeglang, especially Ujung Kulon National Park, because of the website that has been well-known. In the statement number 1 of the questionnaire, namely "In Pandeglang there is Ujung Kulon National Park that has been appointed as one of the world's inheritances under the protection of UNESCO in 1991," the index mean score is 4.780, which implies that Pandeglang has been widely known by the public.

The presence of web-site as the media branding for a city is supported by the aspects that the city has such as place, familiarity toward the city, friendly people, standards of sufficient public facilities and potentially interesting tourism and cultural attractions. These aspects will lead more tourists to visit Pandeglang. Therefore, there should be supports from the Regency of Pandeglang Government and the public as well in promoting Pandeglang. One of the efforts might be branding the Regency of Pandeglang, which has been known because of the Ujung Kulon National Park and the one-horned rhinoceros, as the Regency of Tourism. The test results of the first hypothesis are in accordance to the results of the study by Jannah, Arifin \& Kusumawati (2014), which state that Web Design has significant influence on Re-Visit Behaviour. In the same time, these results have also been confirmed by the 
results of a study by Jesi \& Chandra (2017), which state that Web Design has significant influence on Re-Visit Behaviour. Therefore, it might be concluded that these results have been consistent.

The second hypothesis (H2) states that Electronic Word of Mouth (E-WOM) has positive and significant influence on Re-Visit Behaviour. The T-statistics value for the second hypothesis is $1.645(<1.96)$. Despite the Tstatistics T-value, the finding is in accordance to the statement number 6 in the questionnaire namely "In my opinion the information that has been attained from the social media is highly advantageous as a matter of consideration prior to visiting Pandeglang." The implication of the statement is that the consideration among the tourists has departed from the information that has been found in the social media. The social media that have been widely circulating nowadays such as Visit Pandeglang Instagram Account, Explore Pandeglang, Official Website of the Pandeglang Office of Tourism, Facebook and even YouTube provide complete information about the tourism in Pandeglang. Indeed, social media have been highly influential for the Re-Visit Behaviour to the Regency of Pandeglang because the tourists will decide to visit the Regency after they have read the reviews in the social media. In addition, only by using the hash tag of a destination the tourists will easily identify the pictures that have been uploaded in the social media. Thereby, the tourists will be more interested to visit the destination. The test results of the second hypothesis are in accordance to the results of the study by Fungkiya \& Edriana (2018), which state that E-WOM has positive and significant relationship to Re-Visit Behaviour. Similarly, the results of a study by Heni (2017) also state that E-WOM has positive and significant relationship to Re-Visit Behaviour. In other words, it can be safely considered that these results have been consistent.

The third hypothesis (H3) states that City Branding has positive and significant influence on Visit Decision. However, the results of the study confirm that City Branding has positive but insignificant influence on Visit Decision with the T-statistics value $2.292(<1.96)$. Despite the confirmation, the positive path coefficient value for the third hypothesis shows linear relationship. Therefore, the results of the study assert that City Branding has positive and significant influence on Re-Visit Behaviour. This influence might be explained by the statement that has attained the highest index mean score namely "In my opinion, Pandeglang has unique tourism objectives such as Ujung Kulon National Park with its One-Horned Rhinoceros" and "I am interested to visit Pandeglang because there are many tourism destinations that might be visited, ranging from coastlines to mountains." Such statements might improve the Re-Visit Behaviour among the tourists. Furthermore, based on the significance value, such statements are considered sufficient to generate Re-Visit Behaviour to Pandeglang.

The test results of the third hypothesis are in line with the results of the study by Rizky, Suci \& Aniek (2016), which state that City Branding has positive and significant influence on Re-Visit Behaviour. Thus, it might be inferred that the results of the present study have been consistent. However, the results of the study in this regard are not in line with the results of the study by Risky, Widiartanto \& Sari (2015), which state that City Branding has significant influence on Re-Visit Behaviour. Furthermore, the result of the correlation test is 0.443 , which indicates moderate influence. In the same time, the coefficient of determination is $18.10 \%$, which implies that the size for the contribution of Tourism Product influence in explaining Visit Decision among the visitors of Kreo Cave Semarang has been $18.10 \%$. In the same time, the simple linear regression analysis has resulted in the t-count value that is equal to 4.656 ( $>$ t-table, 1.9845). Consequently, the first hypothesis which states that "Tourism Product has influence on Visit Destination among the visitors of Kreo Cave Semarang" is accepted.

\section{Recommendation}

Departing from the conclusions that have been elaborated in the previous section, there are several suggestions that might be proposed as the matter of consideration for both the Regency of Pandeglang Government and the conduct of the future studies. For Web Design, the indicator with the lowest score is the statement number 6 namely "I do not mind if the Regency of Pandeglang turns into settlement due to its ease of access." The implication of the statement is that most of the respondents do mind if the Regency of is that most of the respondents do not attain sufficient information about the Regency of Pandeglang from the social media. Therefore, there should be specific management in the Internet media so that the supervision on E-WOM within the social media might be monitored well by the caretakers in the Regency of Pandeglang.

Moreover, for City Branding, the indicator with the lowest score is the statement number 1 namely "In my opinion, the infrastructures within the Regency of Pandeglang have been sufficient." The implication of the statement is that most of the respondents regard the infrastructures in the Regency of Pandeglang as insufficient whereas the presence of infrastructures has been very vital in order to ease the tourists to access the tourism objects. Therefore, this matter should be given specific attention by the Regency of Pandeglang Government in the future.

For the future studies, it is expected that the conduct of the present study might provide additional information, knowledge and references with regards to the expansion of instruments, statements and variables for the conduct of the relevant test. On the contrary, there are several aspects that should be reviewed from the present study in relation to the dependent variable and the independent variables such as Accessibility, City Image and alike, so that the conduct of the future studies might be more accurate. In addition, with the use of the more relevant indicators, it is expected that the future studies might explain and clarify other variables and might also identify 
the influence of the given variables on the Visit Decision of the tourists. The reason is that another objective from the conduct of the study is to provide more in-depth and better results toward these variables.

Pandeglang turns into settlement. Therefore, there should be support from the Regency of Pandeglang Government and the public in the Regency to take participation in promoting Pandeglang as a friendly Regency so that the tourists will be interested to visit Pandeglang. The, E-WOM, the indicator with the lowest score is the statement number 1 namely "I decide to visit Pandeglang due to the recommendation from the social media users." The implication of the statement

\section{References}

Bataineh, A., Q. (2015). The Impact of Perceived e-WOM on Purchase Intention: The Mediating Role of Corporate Image. International Journal of Marketing Studies; Vol. 7, No. 1; 2015. Published by Canadian Center of Science and Education

Cahyanti., \& Anjaningrum., (2017). Meningkatkan Niat Berkunjung pada Generasi Muda Melalui Citra Destinasi dan Daya Tarik Kampung Wisata. STIE Asia, Malang. Jurnal JIBEKA, Vol.11,No.1

Cheung, C.M.K, M.K.O., Lee \& D.R. Thadani. (2009). The Impact of Positive Electronic Word of Mouth on Consumer Online Purchasing Decision. Springer-Verlag Berlin eidelberg 2009.

Chen, C., \& Tsai, D. (2007). Manajemen Pemasaran Jasa. Kelompok Gramedia: Indeks.

Donni Juni Priansa (2016). Pengaruh E-WOM dan Persepsi Nilai terhadap Keputusan Konsumen untuk berbelanja Online di Lazada Ecodemica, Vol IV No. 1 April 2016

Fernandez-Cavia , \& Jose et al. (2013). Destination Brands and Website Evaluation : a Research Methodology. Revista Latina de Comunicacion Social, Vol. 68, p. 622-638

Ginting, P. (2005). Pemasaran Pariwisata. Studi Empiris Tentang Kepuasan dan

Kunjungan Berkelanjutan Pariwisata Sumatera Utara. USU Press

Ghozali, I., \& Latan, H. (2014). Partial Least Square Konsep, Teknik Dan Aplikasi Menggunakan Program Smartpls 3.0. Semarang: Universitas Diponegoro Semarang

Heni, S,. (2017). Pengaruh Electronic Word of Mouth Terhadap Keputusan Berkunjung di Sindu Kusuma Edupark. Jurnal Khasanah Ilmu, Vol. 8 No.2, September 2017.

Hening-Thurau,T., Kevin P., Gwinner, Gian, F. W, \& Swayne D., Gremler. (2004). Electronic Word Of Mouth Via Consumer Opinion Platfroms: What Motivates Consumers to Articulate Themselves on the Internet. Journal of interactive Marketing. 38:52.

Hurryati, R., (2015). An Analysis of Place Branding to Enhance the Image of Bandung City and its Implications toward the Decisions to Visit Tourism Destination. Jurnal Pedidikan Sains dan Kemanusiaan, 8 (1) Mei 2015.

Indriani., J.., Kuswoyo., C. (2017). Pengaruh City Branding pada City Image dan Keputusan Berkunjung Wisata Ke Kabupaten Purwakarta Jurnal Manajemen Maranatha, 17 (1) .

Kabupaten Pandeglang-sejarah Kabupaten Pandeglang. (2018, April 02). Retrived from https://id.wikipedia.org/wiki/Kabupaten_Pandeglang

Kotler, P. and Gary, A. (2012). "Principles of Marketing 15th edition". Pearson Education, Inc

Kotler. P \& Keller, K.L (2012). Marketing Management 14th Edition, New Jersey: Pearson Education, Inc

Lilis R, N. Pengaruh (2015). City Branding terhadap Image Of Urban Destination dan Dampaknya pada Post-Visit Behavior Trikonomika Volume 14, No. 1, Juni 2015

Lubis, M. S. W. (2018, Maret 27). Banten Bidik 15,1 Juta Wisatawan. Retrived from https://banten.bisnis.com/read/20180327/422/754633/banten-bidik-151- juta-wisatawan

Obyek wisata di Kabupaten Pandeglang tahun 2015 sampai dengan 2017. (2018, Juli 06) Retrived from https://www.dispar.pandeglang.go.id/

Pandeglang dalam angka 2015. (2015, Feberuari 10). Retrived from https://pandeglangkab.bps.go.id/publication/2016/02/10/4336d5a61aa1cb394ab299e0/kabupatenpandeglang-dalam-angka-2015.html

Pandeglang dalam angka 2016. (2016, Juli 15$)$. Retrived from https://pandeglangkab.bps.go.id/publication/2016/07/15/ce5e3e4d33df790f67f25832/kabupatenpandeglang-dalam-angka-2016.html

Pandeglang dalam angka 2017. (2017, April 23). Retrived https://pandeglangkab.bps.go.id/publication/2017/08/11/91a742e6e87ba1c717c1d989/kabupatenpandeglang-dalam-angka-2017.html

Panduan trip pergi liburan ke Pandeglang. (2018, April 02). Retrived from https://pergimulu.com/panduan-tipspergi-liburan-ke-pandeglang/

Penggguna internet di Indonesia tahun 2017. (2018). Retrived from https://apjii.or.id/downfile/file/ Survei Internet APJII 2017.pdf

Perkembangan jumlah kunjungan wisatawan nusantara dan mancanegara kabupaten pandeglang tahun 2015 sampai dengan 2017. (2018, Juli 06). Retrived from https://dispar.bantenprov.go.id/ 
Ratnaningrum., Suwarduki.P., Yulianto., Edy., Kholid, M., \& Mawardi. (2016) Pengaruh Electronic Word Of Mouth Terhadap Citra Destinasi Serta Dampaknya terhadap minat dan Keputusan Berkunjung (Survei pada Followers Aktif Akun Instagram Indtravel yang Telah Mengunjungi Destinasi Wisata di Indonesia. Jurnal Administrasi Bisnis (JAB)|Vol. 37 No. 2 Agustus 2016

Rheza, S., Alfattory. (2015) Pengaruh Daya Tarik, Fasilitas dan Askesibilitas Terhadap Keputusan Wisatawan Asing Berkunjung Kemabli Ke Aloita Resort di Kab. Mentawai Vol. 7 No.1 Tahun 2015 journal.stkip-pgri sumbar.ac.id/index.php/pelangi

Rizki, A., Maharani., \& Pangestuti, E. (2017). Pengaruh terapan Media Sosial Instagram Terhadap Citra Destinasi dan Dampaknya pada Keputusan Berkunjung (survey pada Pegnjung Kampung Warna Warni Jodipan, Kota Malang). Jurnal Administrasi Bisnis (JAB)|Vol. 49 No. 2 Agustus 2017

Sari F,. \& Pangestuti, E. (2018) Pengaruh Electronic Word of Mouth (EWOM) Terhadap Minat Berkunjung Berkunjung dan Keputusan Berkunjung (Studi Pada Wisata Coban Rais BKPH Pujon). Jurnal Administrasi Bisnis (JAB) Vol.54 No.1, Januari 2018

Saputri, A., Fatimatus,. Fauzi, A., \& Irawan, Ari. (2018). Pengaruh City Branding terhadap City Image dan Keputusan Berkunjung Ke Kota Wisata Batu (Survei pada Wisatawan yang Berkunjung ke Kota Wisata Batu). Jurnal Administrasi Bisnis (JAB)|Vol. 54 No. 1 Januari 2018.

Schiffman, L., G. \& Kanuk, L., L. (2010). Consumer Behaviour, Edisi 10. New Jersey: Pearson Education Limited. Sudaryono. 2014. Perilaku Konsumen Dalam Prespektif Pemasaran. Jakarta: Lentera Ilmu Cendekia.

Sugiyono. (2013). Metode Penelitian Bisnis. Bandung: Alfabeta

Tjiptono, Fandi. 2011. Brand Managemet \& Strategy. Malang: Bayu Media Publishing

Wandari, L., Kumadji, A., Srikandi., \& Kusumawarti, A. (2014). Pengaruh City Branding "Shining Batu" Terhadap City Image dan Keputusan Berkunjung Wisata ke Kota Batu Jurnal Administrasi Bisnis (JAB). Volume. 16, No.1 1 November 2014

Yananda, M., Rahmat., Salamah., \& Ummi (2014). Branding Tempat; Membangun Kota, Kabupaten, dan Provinsi Berbasis Identitas. Jakarta: Makna Informasi.

Yoeti, A., O. (2008) Ekonomi Pariwisata :Introduksi, informasi dan implementasi. Jakarta: Kompas 